\title{
The Role of Maritime Education and Training of Young Adults in Creating a Strategic Model for the Management of a Public Diplomacy Project
}

\author{
A. Czarnecka \& K. Muszyńska \\ Gdynia Maritime University, Gdynia, Poland
}

ABSTRACT: The article focuses on the issues of maritime education and training of young adults as a tool of public diplomacy. In the first part, the authors present a contemporary approach to the tools and tasks of public diplomacy used for strengthening the image of the state.

\section{INTRODUCTION}

Public diplomacy is a form of international communication. It is perceived as the most important tool of soft power - an indispensable tool these days for building the power of the state and its position in the international environment [Ociepka B. 2013]. It is used in parallel with the national branding so they complement each other and make a modern tool for building the State's image in a long term.

From the point of view of public diplomacy, the centenary of the restoration of Poland's independence can be perceived as a vehicle for values that should be communicated at home and abroad. In Poland, the communicated values such as patriotism, the joy due to regaining sovereignty and the sense of national identity were expressed in a form of events aiming at strengthening the image of the state and were organized by various governmental and nongovernmental institutions. On the other hand, abroad, the event resonated around the globe in a form of an undertaking known as the Independence Sail. The aim of the 10-month project was to promote and draw attention to Poland in order to raise its profile in the world.
The link for the marketing message of the Independence Sail was the young people participating in the project including the GMU ${ }^{1}$ students from Navigation Department taking their obligatory seamanship training. The design of the training program for all the participants of the Independence Sail, allowed soft communication of essential values to improve the country image such as patriotism, unity, identity, without intrusive advertising.

\section{ORGANIZATION AND IDEA BEHAIND THE INDEPENDACE SAIL}

The anniversary of the restoration of Poland's independence coincides with the anniversary of the Polish Merchant Navy creation. Seventeen days after regaining independence by Poland, and a year and a half before getting an access to the sea, Józef Piłsudski ${ }^{2}$ on November 28, 1918 issued an order to

\footnotetext{
${ }^{1}$ GMU - Gdynia Maritime University

2 Józef Piłsudski - a Polish Chief of State and First Marshal of Poland
} 
establish the Polish Navy. Therefore, the idea of organizing a cruise around the world with the largest Polish sailing vessel the Dar Młodzieży on the occasion of Poland's regaining Independence was a coherent idea, in a clear manner corresponding to the ideograms of the anniversary - the sea, white-and-red flag, educating and developing young people.

The organizer of this undertaking was the Ministry of Maritime Economy and Inland Navigation, the Maritime University of Gdynia and the Pallottine Missionary Foundation Salvatti.

The selection of the organizers was not accidental. The Ministry's involvement resulted from its position in the structure of government administration as a supervisory body responsible for pursuing policy in the field of maritime economy, as well as overseeing the Maritime University of Gdynia - a university training maritime personnel.

Being the oldest and the largest maritime school of higher education in Poland ${ }^{3}$, the shipowner of the Dar Młodzieży and a representative of the Polish merchant navy, the Maritime University of Gdynia was particularly well positioned to organize the adventure.

In turn, the Pallottine Missionary Foundation Salvatti was an organization co-creating the program of the Polish presence during the World Youth Day in Panama - one of the main ports of call.

The organizers' tasks for the Independence Sail were arranged in accordance with the areas of responsibility of individual entities. The Ministry was responsible for cooperation with the Ministry of Foreign Affairs by creating and supervising the program of official visits of representatives of the Polish government in the ports where the Dar Młodzieży called. In the case of the Independence Sail, the program of visits for individual ports was coordinated by the Ministry of Maritime Economy and Inland Navigation, as the ministry is indicated in the Resolution of the Council of Ministers of October 31, 2017 on the organization of the Dar Młodzieży cruise around the world to celebrate the 100th anniversary of regaining independence by the Republic of Poland. The Council of Ministers obliged the minister of Maritime Economy and Inland Navigation to coordinate activities related to the organization of the cruise circumnavigating the world. The Ministry signed an agreement on this matter with the Maritime University in Gdynia and the Pallottine Missionary Foundation Salvatti. As a coordinator of program activities, worked closely with the Ministry of Foreign Affairs and consular posts and embassies of countries visited by the Dar Młodzieży, which in turn were responsible for organizing official delegations welcoming the Dar Młodzieży and festivities.

The Maritime University of Gdynia was responsible for the technical aspects of the project and the training process of the participants during the cruise. The Maritime University, as a co-organizer of the cruise, participated in the development of programs for stays in ports, organizing meetings for representatives of maritime economy, organizing meetings of students and representatives of maritime universities, and establishing long-term relationships. The role of the organizer was also associated with responsibility for the safety and education on board the Dar Młodzieży. On boarding the vessel, all participants of the cruise were obliged to submit to the captain of the ship and were treated like cadets, which meant participation in standard seamanship training, watch-keeping including on-call duties in the galley, engine room, attending sails, deck washing, etc.

Meanwhile, the Missionary Foundation Salvatti was responsible for spiritual care over the participants of the cruise and preparing them for the World Youth Day in Panama.

A significant element communicating the idea of the Cruise in the country was a competition called My Fatherland. ${ }^{4}$, in which took parts young Poles between 18 and 25 years old. They had to demonstrate knowledge of the history of Poland, maritime terminology and the subject of sea exemplification in the Bible. The tasks of the cruise promotion were divided among all three organizers and institutions directly related to the government - the Ministry of Foreign Affairs, Polish Institutes and Polish embassies in the countries visited. Actions taken by all these entities were a part of the public diplomacy.

\section{THE ESSENCE AND SPECIFICITY OF PUBLIC DIPLOMACY}

Public diplomacy aims at developing the desired image of the country, adapting the appropriate forms of promotion abroad and identifying target groups. A characteristic feature of public diplomacy is the fact that promotional activities are carried out mainly by entities which are not related to governmental administration. An important role is played by nongovernmental institutions, including local selfgovernment institutions [Studzieniecki T. 2017], whose tasks include the creation of the desired image of the country. It covers all sorts of activities where main or secondary objective is to promote elements of the country's brand, to shape favorable public opinion on Poland, to spread knowledge about the country, its history and the contribution of Poland and Poles to the development of Europe and the world. In the Polish legal system, the institution responsible for conducting public diplomacy is the Ministry of Foreign Affairs.

Public relations instruments are basic tools for conducting public diplomacy activities such as: organization of events, press conferences, building relations with the media, press materials, publications, and communication on the Internet [Rozwadowska B 2001].. 


\section{ELEMENTS OF PUBLIC DIPLOMACY BY AN EXAMPLE OF THE INDEPENDENCE SAIL}

An important role in the promotion of the Independence Sail was played by meetings held in each port with visitors to Dar Młodzieży and events organized for the benefit of a wider audience.

A perfect example was the port of Bordeaux, where the Dar Młodzieży visited on June 27-29, 2018. The organizer of events, related to the stay of the tall ship, was the Polish consulate in Paris and the Polish Institute in Paris. During the two-day stay, the Dar Młodzieży could be visited free of charge, and the invited guests participated in meetings related to the idea of the Independence Sail. A press conference for local journalists was organized, during which the Independence Sail was presented in the context of the $100^{\text {th }}$ anniversary of regaining independence by Poland, with an aperitif and sightseeing of the ship.

An attraction for all visitors and passers-by was a cultural event - an acrobatic performance of the Polish acrobatic group Mira Art on ropes hung between the Dar Młodzieży masts. The show was preceded by a reception given by the ambassador on the ship for individuals representing political, public and academic circles from Bordeaux and Paris. In the twoday program of the Dar Młodzieży visit in Bordeaux, there was also a meeting connected with a presentation of Poland's economy, prospects and opportunities - the guests of the Ambassador were the people involved in economy and the President of the New Aquitaine Economic Zone. The meeting was hosted by a representative of the Polish Embassy in Paris with the participation of the Head of the Foreign Trade Office in Paris and the head of the branch of the Polish company Comarch in France. Another group targeted at the promotion of Poland was tourism operators. The stay of the Dar Młodzieży in Bordeaux is an example of using crucial public relations tools and coordinating the image campaign conducted in various areas - politics, culture, education, and tourism.

The difficulty of managing the image of the country and coordinating the image campaign is that in the type of diplomacy " $\mathrm{p} 2 \mathrm{p}$ " (people to people, without an involvement of the government) the main campaign leaders are non-governmental organizations, while in the economic dimension organizations and companies supporting business, which should also be perceived as leaders of image campaigns.

In the case of the Independence Sail, both groups coexisted and were pursuing their goals. Governmental institutions got focused on the official welcome celebrations of the Dar Młodzieży in ports which enabled the hosts of the country and the region and their Polish counterparts to present their country and government.

Business leaders, on the other hand, used the presence of a beautiful sailing ship to organize business meetings, during which they presented their potential in an informal atmosphere.

Public diplomacy is also defined as a Strategic Communication utilized by states to influence public opinion abroad [Ociepka B. 2013]. Assisted by the soft power - contributes to the building of the power of the state and its profile abroad. It is implemented in three dimensions: information management, strategic communication and relationship build-up.

The first dimension includes standard cooperation with foreign correspondents who play the role of multilink by providing information and creating a context for understanding the events. Strategic communication is subordinated to the strategic goals of the government - in the case of the Independence Sail it was the celebration of the 100th anniversary of Poland's independence.

Strategic communication is part of a long-term planning in which appropriate resources are adapted to achieve the most important goals over the longer term. Building relationships is the last complementary dimension of public diplomacy. It is obtained through joint work and presence at events that create a positive image, such as exhibitions, concerts, parties, events, press conferences and alike. Cooperation between Polish institutions and countries visited by the Dar Młodzieży resulted in an increased number of media feeds on Poland in both foreign and Polish media, broadcast a few days before and a few days after the vessel's arrival at a given port.

In every port visited by the Dar Młodzieży, press conferences, visits of journalists onboard the Dar Młodzieży were organized. Moreover, well-chosen press materials and advertising stuff were available. Meetings and conferences were organized by consular authorities in cooperation with local authorities. Materials for the media were prepared by the organizers of the Cruise - Maritime University in Gdynia and the Press Office of the Ministry of Maritime Economy and Inland Navigation.

Due to multidimensional and multithread nature of public diplomacy, the coordination of the activities of diverse entities becomes a key issue. This coordination is usually at the discretion of governments, especially ministries of foreign affairs. In Poland, the issue of coordination concerns not only relations between state and non-state institutions, but communication between individual ministries, as well. Typically, the coordinating centre is the Ministry of Foreign Affairs. In the case of the Independence Sail, the coordinating centre was the Ministry of Maritime Economy and Inland Navigation.

\section{SEAMANSHIP TRAINING}

The seamanship training on board the Dar Młodzieży was not only a carrier of educational element during the Independence Sail, but also served shaping the character of the young trainees [Mezirov J.2006]. Thus, important values from the point of view of public diplomacy were communicated by presenting Poles as a nation with a well-formed national identity and solidarity, brotherly, and strong.

The education process at the Maritime University in Gdynia is conducted in accordance with respective and approved national curricula. Seamanship training offered by Gdynia Maritime University makes a part of the curriculum. In addition, the students take 
training in a simulator-based environment. The training process depends on the field of study.

The curricula for an individual faculty and the field of study cover the details contained in the syllabus for Training in a simulator-based environment. Each of the faculties has included detailed guidelines for a given type of practice or a course in a simulatorbased environment, in accordance with the field of study and specialization for students educated in accordance with the STCW Convention (International Convention on Standards of Training, Certification and Watchkeeping). Seamanship training on board ships and simulator-based classes are an integral part of the curriculum.

The seamanship training performed on board of ships of the Maritime University in Gdynia, as well as merchant vessels, is a practical preparation of students to perform the function of sailor in the future. Students educated in accordance with the STCW are obligated to complete 12 months of the supervised seamanship training.

In order to achieve the assumed learning outcomes, the seamanship training is based on the approved internship book for departments respectively (Navigational, Mechanical, Electrical). Verification of the completed training is done by authorized dean, who double checks records in the student's training book, and approves it after that. In the case of incorrect or shortage of some records, the student is obliged to complete the book on board of the ship and then submit it to check and approve by the dean. The seamanship training is the compulsory element which has to be completed to obtain the navigation, mechanic or electric officer diploma.

Seamanship training conducted on training ships of the Maritime University of Gdynia is an indispensable element of the marine education and a process of shaping young adults as future seafarers confirmed by years of experience.

A merchant navy officer, a ship's engineer or a ship's electrician, in order to be a well-educated specialist, must, apart from the theoretical knowledge and training in a simulator-based environment, be thoroughly trained in the real-life on-board environment on the "Dar Młodzieży", "Horizon II" and merchant navy vessels. The apprenticeship is a mandatory element to become legally a certified ship's officer and results from the national regulations ${ }^{5}$ and the provisions of the international STCW Convention ${ }^{6}$. The same or very much alike rules are in force at other maritime universities in the world to meet the standardized criteria for the issuance of international seafarers' certificates of competency.

The seamanship training on board the ships of the Maritime University of Gdynia is realized with respect to traditional values, developed on the basis of a long-term seagoing experience of the crew, progress in the maritime industry and technology as well as

\footnotetext{
5 Regulations of the Minister of Transport of Construction and Maritime Economy on the training and qualifications of crew members of sea-going ships

${ }^{6}$ http://www.imo.org/en/OurWork/HumanElement/TrainingCertif ication/Pages/STCW-Convention.aspx
}

guidelines and suggestions collected from faculties and schools of similar profile. The implementation of the training should, in particular, take into account in the provisions of the International Convention on Standards of Training, Certification and Watchkeeping for Seafarers.

The STCW Convention requirements are met on board a ship by implementing appropriate apprenticeship programs as well as cadet training record books for the deck, engine and electrical departments respectively.

The hard rules of the on-board service make traits necessary for later service as navigators on modern merchant vessels [Diduk A. 2012]. Seamanship training on board a training vessel is very often the first ever contact with the hardships of seafarer's life, what allows to confront and verify the ideas and theory of work at sea with reality. The shipboard training on the "Dar Młodzieży" provides future seafarers with principles of good seamanship, all the right skills to do the job safely and responsively, teaches team-work, develops marine awareness, as well as physical fitness and mental resilience.

It is extremely important to instill the rules of life at sea and shape the behavior of a future seaman based on good maritime practice, i.e. "the usual way of behaving, reacting, facing certain conditions and circumstances of an experienced, efficient and diligent seaman. This is a procedure that is perpetuated by permanent use, commonly known to seafarers, reasonable, effective and proven in the prevention of accidents at sea. The rules of seamanship created on the basis of the experience of many generations of seafarers become, over time, habits sanctioned by the jurisprudence of chambers and maritime courts. Many of them are adopted over time and enter the maritime law e.g. the COLREG regulations." [Rymarz W. 1985].

Shipboard practice teaches teamwork and responsibility and allows trainees to become aware and responsible seafarers not only to guarantee their safety but also other crew members.

Researches in the field of education confirm value of transformation, particularly performed in the form of educational internships. However, despite the significant role of transformational education in education of adults, there is a small number of studies, which determine to what extend transformation and education, in the field of maritime education, can be integrated. [Christie M. 2009]

Training ships offer familiarization with the essentials and cadets are taught maritime customs, skills to handle the vessel safely and efficiently to, read the sea and weather and daily upkeep of the vessel. The training is completed by students of all maritime specialties - navigators, engineers, electricians and stewards. Transformation of learning in the field of education, for sustainable development, requires commitment of all areas of education, departments and students' involvement [Leal Filho W. 2018].

Another practice is an advanced training for students of the Navigational, Mechanical and Electrical Departments. At this stage the cadets learn to work with charts, operate navigational instruments 
on the training bridge, and assist in the engine room during watchkeeping and take part in minor repairs and maintenance works in the engine room.

\section{THE CRUISE AS AN EDUCATIONAL PROJECT}

Students of the Maritime University in Gdynia, students of maritime schools, as well as laureates selected in the competition took part in the Independence Sail. For the participants, the cruise was not only a sea voyage, but also a unique opportunity to make dreams come true and visit many distant countries. The competition consisted of two stages in which contestants had to submit photos or a short film presenting themselves as young ambassadors who, by showing the values and beauty of their "Little Homeland" will promote Poland abroad. The second stage was a test on knowledge about Poland. During the competition, 400 winners were selected. Everyone was obliged to be a holder of the international maritime health certificate issued following a medical examination by a maritime medical practitioner. Following that, the participants took part in the following specialized training courses:

- in the field of basic medical aid,

- in the field of personal safety and social responsibility,

- in the a field of personal survival techniques,

- in the field of basic fire prevention and firefighting,

- in the field of shipboard security.

Having met all the above requirements, the laureates applied to the Maritime Office to obtain seaman's books.

The laureates were obliged to have the same documents and training as students so that they could be embarked and obtain the cadet status. Everyone, on equal terms, was assigned daily watchkeeping and upkeep duties. During the internships, they took part in setting sails, maintenance works, washing the deck, repairing and sewing sails, as well as watches in the engine room, galley and pantry. During the voyage the students and laureates had the opportunity to learn the basics of navigation, astronavigation, meteorology, ship's knowledge, ship's operation, as well as the basics of good seamanship. The internship was conducted in accordance with a usual timetable. The whole process of training was supervised by the ship's master, the crew, and cadet trainers appointed by the university.

The Independence Sail was attended by 472 students, 62 cadets and 400 laureates who changed over at selected stages of the cruise, what illustrates table number 1 .
Table 1. Number of students, cadets and laureates at selected stages of the Independence Sail.

\begin{tabular}{lccc}
\hline $\begin{array}{l}\text { The place of } \\
\text { embarkation } \\
\text { and } \\
\text { disembarkation }\end{array}$ & $\begin{array}{l}\text { The number } \\
\text { of embarked } \\
\text { students }\end{array}$ & $\begin{array}{l}\text { The number } \\
\text { of embarked } \\
\text { cadets of the } \\
\text { maritime } \\
\text { schools }\end{array}$ & $\begin{array}{l}\text { The number } \\
\text { laureates }\end{array}$ \\
\hline $\begin{array}{c}\text { Gdynia - } \\
\text { Kopenhaga }\end{array}$ & 0 & 62 & 70 \\
$\begin{array}{c}\text { Kopenhaga - } \\
\text { Szczecin }\end{array}$ & 0 & 62 & 70 \\
$\begin{array}{c}\text { Szczecin - } \\
\text { Teneryfa }\end{array}$ & 54 & 0 & 82 \\
$\begin{array}{c}\text { Teneryfa - } \\
\text { Kapsztad }\end{array}$ & 108 & 0 & 28 \\
$\begin{array}{c}\text { Kapsztad - } \\
\text { Singapur }\end{array}$ & 100 & 0 & 36 \\
$\begin{array}{c}\text { Singapur - } \\
\text { Osaka }\end{array}$ & 110 & 0 & 26 \\
$\begin{array}{c}\text { Osaka - } \\
\text { Los Angeles }\end{array}$ & 110 & 0 & 26 \\
$\begin{array}{c}\text { Los Angeles - } \\
\text { Panama }\end{array}$ & 110 & 0 & 26 \\
$\begin{array}{c}\text { Panama - } \\
\text { Gdynia }\end{array}$ & 100 & 0 & 36 \\
\hline
\end{tabular}

The route Gdynia-Tallinn-Copenghagen was attended by 330 students from the Maritime School in Świnoujście, 29 students from the West Pomeranian Maritime and Polytechnic Education Centre and 70 laureates. The next stage from Copenhagen to Szczecin, taking the route leading through Stavanger was attended by the same school students, but 70 laureates were changed over with new ones. Then, in Szczecin, 54 students of the Faculty of Electrical Engineering of the Maritime University and 82 laureates sailed to Tenerife, staying for a few days at the ports of Bremerhaven and Bordeaux. In Tenerife, there was another exchange of 28 laureates and a new group of 108 sophomores from the Navigational Faculty of the Maritime University joined the vessel. Their route led through Dakar, where the ship stayed on 18-20.07.2018, and then sailed to Cape Town, where a new group of 36 winners and 100 of sophomores from the Faculty of Mechanical Engineering embarked. Next, the ship sailed through Mauritius, Jakarta, to reach Singapore on October 9, where another 110 students of the first year from the Navigational Faculty and 26 laureates joined the vessel replacing others. Subsequent exchanges of laureates took place in the ports of Osaka, Los Angeles and Panama, where they were also changed over after a long three-month practice of students. The last stage from Panama to Gdynia, calling at the ports of Cartagena, Miami, Bahamas, Ponta Delgada and London was attended by 100 students of the Faculty of Mechanical Engineering of the Maritime University and 36 laureates. The cruise terminated in Gdynia on March 28, 2019.

The participants of the cruise had a unique opportunity to take part in the great undertaking under the name of the Independence Sail, as well as the seamanship training. Moreover, they took part in a variety of cultural events, visited maritime colleges and met a lot of people in ports where the Dar Młodzieży - Ambassador of the Republic of Poland called. 


\section{CONCLUSIONS}

The Independence Sail was not only the educational and promotional project, but it is also very interesting study in the case of public diplomacy. Thanks to the management of the soft resources and utilizing of checked and good operating system of seamanship training, thanks to skillful management of public relations tools in international communications, and therefore utilizing of a soft power, the project of the Sail, supported building of the Poland's position in the international environment and become the State's image in a long term. It allowed to present Poland as a country proud of its history with coherent national identity, strong and persistent in overcome difficulties.

\section{BIBLIOGRAPHY}

[1] Christie, M. (2009). Transformative learning - in action Christie, The proceedings of the 9th Annual conference on Active Learning in Engineering Education (ALE), Barcelona, Spain 9-12 June 2009. Available: http://upcommons.upc.edu/revisit/bitstream/2099/7803/1 /ale09-paper10.pdf.

[2] Diduk A. (2012). Transformative Learning Theory, Public Involvement, and Natural Resource and Environmental
Management, Journal of Environmental Planning and Management 55 (10):1-20, December 2012.

[3] Leal Filho W., Raath S., Lazzarini B., Vargas V.R., de Souza L., Anholon R., Quelhas O.L.G., Haddad R., Klavins M., Orlovic L.V., The Role of Transformation in Learning and Education for Sustainability, Journal of Cleaner Production (2018), doi: 10.1016/j. jclepro.2018.07.017.

[4] Mezirow J. (2006). An Overview on Transformative Learning, [in:] K. Illeris (ed.), Contemporary Theories of Learning, Routledge, London.

[5] Ociepka B. (2013). Miękka siła i dyplomacja publiczna Polski, Warszawa 2013.

[6] Rozwadowska B. (2001). Public Relations, Warszawa 2001.

[7] Rozporządzenie Ministra Transportu, Budownictwa i Gospodarki Morskiej z dnia 7 sierpnia 2013 r. w sprawie wyszkolenia i kwalifikacji członków załóg statków morskich.

[8] Rymarz W., Międzynarodowe prawo drogi morskiej, Wydawnictwo Morskie Gdańsk, 1985

[9] Studzieniecki T. (2018). Dyplomacja samorządowa w Polsce - aspekty ekonomiczne i społeczne, [in:] Świerczewska-Pietras K., Pyra M. (ed.) Wyzwania polityki regionalnej $\mathrm{w}$ aspekcie rozwoju społecznogospodarczego obszarów transgranicznych, Biała Podlaska, pp. 319-341.

[10] http://www.imo.org/en/OurWork/HumanElement/Trai ningCertification/Pages/STCW-Convention.aspx 